INTERNATIONAL HIGHER EDUCATION, Number 73 Fall 2013

Pages 23-24

\title{
Venezuelan Higher Education's Legacy Under Chávez
}

\author{
ORLANDO ALBORNOZ \\ Orlando Albornoz is professor at the Universidad Central de Venezuela, Caracas. \\ E-mail: oalborno@reacciun.ve.
}

Hugo Chávez, who is now gone, was in power for a rather long period, 19992013, and tried to introduce many changes in higher education. While there has been an ongoing line of policy in operation of this system, he did not manage to oppose that plan. In 1830 the universities were nationalized. However, in 1953 the private sector was allowed to participate in this academic market. In 1958, a democratic revolution took power, and the university system was expanded and modernized. Of course, the Chávez Bolivarian revolution intended to change all that. He ran out of time, however, and the higher education system remains in 2013 much like the one he inherited in 1999. While the structure and organization of higher education have not changed, in 1999 the state (i.e., public) universities had 510,917 students and in 2011 1,132,306; the private sector had 299,664 students in 1999 and 555,198 in 2011. Yet, the growth of state institutions had slowed down in the last three years.

While the higher education system in Venezuela did not begin or will end with him, Hugo Chávez, however, left a legacy in the system. He opened two universities that are right now the largest in the country-opening access to thousands of students who otherwise would not have entered higher education. 
Partly, lacking the required qualifications and members of the poor population, those students also had fewer expectations to enter higher education. Thus, it would be a risk to earn professional degrees that would open the labor market to them, even if it was state employment. This expansion follows the Cuban model of the munipalizacion of the universities, and full control by the state, in this case eliminating the role of the autonomous universities. Chávez only had a vision of the universities, as goals of the revolution. Thus, he established these universities on a Marxist-doctrinarian approach, which will impede these universities from becoming a various knowledge section.

\section{MODERNIZATION: 1958}

In 1958, the Venezuelan higher education system established modern characteristics of autonomy, democratic governance, the professionalization of the academic staff, the establishment of many diverse institutions, larger members of the population, not only with the dominant role of the upper class, and the universities responding to social demands. The higher education system expanded strongly throughout the country. In 1990, the country opened a general plan to identify and finance scientific research, and graduate studies began to be opened in several state institutions. In those four decades, the system was a success and managed to create the political leaders and professionals in all positions-to point out that a new social class was created and legitimated the middle class. However, the system was inefficient: it could not open positions at universities for the growing demands. In spite of positive training, professionals were unable to advance to open up research universities, which were being established all through Latin America. 


\section{The Higher Education System}

Chávez inherited higher education based on a well-established and diversified system, with universities and other institutions covering the needs of society, with both the state and the private sector providing a good service to society. However, major mistakes were introduced as well. In 1975, the state opened a vast program that provided scholarship for university students to go abroad, trying to accelerate the training of human resources. Thousands of Venezuelan students were sent to Europe and the United States, not all of them returning with their professional degrees. This was done instead of doing what was mostly needed-strengthening the quality of the universities and bringing from abroad the necessary academic staff. Chávez committed a similar error when he sent thousands of students to Cuba.

However, Chávez left the higher education system unchanged, in spite of all the rhetoric about his political and ideological revolution. He applied policies to expand access, tried to follow in toto the Cuban model of the universityabsolute state control. The universities under his government control became institutions dedicated to train staff based on the revolution rather than professionals for the market-both militarized and run under strict doctrinarian lines of thoughts. In his scheme to govern the universities, the universities were to be run not by the members of the staff and the students but also with the participation of administrative employees and manual workers.

Instead of trying to issue policies that would be applied to all universities, Chávez created new institutions, to cover the needs of the revolution, not of 
society. He left the conventional system to operate but introduced his own group.

\section{QUALITY AND THE FUTURE}

The Venezuelan higher education system exhibits the inability to support advances in quality, which are the goals in many countries and institutions. Some data provided by both the Shanghai and the Times Higher Education university rankings show that the Venezuelan universities are lagging behind most countries of the region. Solely, the revolution tried to create its own socialist vision, isolated from the international flow of knowledge, which is obtained via globalization and internationalization.

As for the future, the higher education system depends on the political as well as the economic situation. If Chávez's successors were able to remain in power, regulation would be accelerated and the state would take full control of higher education. The fact is, however, that the years of the financial largesse of the government during the years of Chávez have finished. Venezuela is about to enter a period of reduction, which would cause conflicts at the universities. Of course, this society seems to work well when funds are available without restriction-including the academic system. There is plenty of room for a reform that could put the universities back on track.

\section{Closing the Venezuelan Mind}

Chavez's achievements on higher education were modest in performance and greatly exaggerated by the government propaganda. The damages to the autonomous universities and to the academic development of Venezuela, 
however, are serious. As the lack of public support and the misunderstanding about the role of higher education in society, steps were taken by the now deceased leader during his 15 years in power-expanding student access and closing the Venezuelan mind. 